Article

\title{
Specific and Cumulative Exhaust Gas Emissions in Micro-Scale Generators Fueled by Syngas from Biomass Gasification
}

\author{
Marco Puglia ${ }^{1, *}$, Nicolò Morselli ${ }^{1}$, Simone Pedrazzi ${ }^{1}$, Paolo Tartarini ${ }^{1,2}$, Giulio Allesina ${ }^{1,2}$ (D) \\ and Alberto Muscio 1,2 (D) \\ 1 Department of Engineering “Enzo Ferrari”, University of Modena and Reggio Emilia, Via Pietro Vivarelli, \\ 10-41125 Modena, Italy; nicolo.morselli@unimore.it (N.M.); simone.pedrazzi@unimore.it (S.P.); \\ paolo.tartarini@unimore.it (P.T.); giulio.allesina@unimore.it (G.A.); alberto.muscio@unimore.it (A.M.) \\ 2 Centro Interdipartimentale INTERMECH, University of Modena and Reggio Emilia, Via Pietro Vivarelli, \\ 2-41125 Modena, Italy \\ * Correspondence: marco.puglia@unimore.it; Tel.: +39-059-205-6229
}

Citation: Puglia, M.; Morselli, N.; Pedrazzi, S.; Tartarini, P.; Allesina, G.; Muscio, A. Specific and Cumulative Exhaust Gas Emissions in Micro-Scale Generators Fueled by Syngas from Biomass Gasification. Sustainability 2021, 13, 3312. https://doi.org/ $10.3390 /$ su13063312

Academic Editor: Dino Musmarra

Received: 19 February 2021

Accepted: 15 March 2021

Published: 17 March 2021

Publisher's Note: MDPI stays neutral with regard to jurisdictional claims in published maps and institutional affiliations.

Copyright: (C) 2021 by the authors. Licensee MDPI, Basel, Switzerland. This article is an open access article distributed under the terms and conditions of the Creative Commons Attribution (CC BY) license (https:/ / creativecommons.org/licenses/by/ $4.0 /)$.

\begin{abstract}
Climate change, environmental degradation, and biodiversity loss are prompting production systems to shift from a fossil-based economy to a circular bio-based one. In this context, biomass gasification is a promising alternative to fossil fuels that can contribute to power generation in rural communities and remote areas as well as provide a sustainable source of energy for developed countries. In this work, exhaust gas emissions $\left(\mathrm{CO}, \mathrm{NOx}\right.$, and $\left.\mathrm{SO}_{2}\right)$ of two syngas-fueled micro-scale generators were measured. The first system is a commercial biomass gasifier genset, whereas the second is composed of a laboratory-scale gasifier prototype and a portable petrol generator. For this second facility, emissions were measured both running on gasoline and on syngas. The comparison was performed both on the pollutant concentration and on their cumulative amount. This comparison was made possible by calculating the exhaust gas flow by knowing the combustion stoichiometry and fuel consumption. The results showed a much lower pollutant concentration running on syngas compared to gasoline. In particular, considering the best configurations, every cubic meter of exhaust gas released running on syngas contains about 20 times less $\mathrm{CO}$ and almost one-third less NOx compared to gasoline. Moreover, the cumulative amount of emissions released was also considerably lower due to the lower exhaust gas flow (about 25\%) released running on syngas.
\end{abstract}

Keywords: emissions analysis; biomass gasification; portable generator; syngas; gasoline; engine

\section{Introduction}

Climate change, along with degradation of the environment with consequent biodiversity loss, is prompting production systems to shift from a fossil-based economy to a circular bio-based one [1]. Biomass is a promising alternative to fossil fuels for electrical power generation [2]. Biomass is widely available, uniformly distributed, and less intermittent compared to other renewable sources like wind power and solar photovoltaic, which are not always available when needed [2]. Furthermore, the growth of bioenergy can increase food supply, economic growth, and female employment [3].

In particular, biomass gasification can contribute to power generation in rural communities and remote areas where access to electric power is obtained by using electric generators coupled to compression-ignition or spark-ignition engines [2]. Additionally, it can provide a sustainable source of energy for developed countries [4].

Gasification consists of the conversion of a carbonaceous material, such as biomass, into a synthetic gaseous fuel, called syngas [5], composed mostly of carbon monoxide (CO), carbon dioxide $\left(\mathrm{CO}_{2}\right)$, methane $\left(\mathrm{CH}_{4}\right)$, hydrogen $\left(\mathrm{H}_{2}\right)$, and nitrogen $\left(\mathrm{N}_{2}\right)$ [6] as well as char, ash, tar, and oils [7]. Syngas can be used in spark-ignition engines as an alternative to gasoline [5]. Fossil fuels are the leading cause of air pollution, greenhouse gas (GHG) emissions, and climate change [8]. 
It has been demonstrated that fossil fuel combustion is the major source of nitrogen oxide (NOx) and black smoke (suspended particulate matter less than $15 \mu \mathrm{m}$ ) emissions [9]. Another pollutant produced through combustion is $\mathrm{CO}$ [10], one of the main contributors to air pollution due to its high toxicity [11]. Furthermore, sulfur-containing fossil fuel combustion is responsible for most of the sulfur dioxide $\left(\mathrm{SO}_{2}\right)$ content in the atmosphere [12]. $\mathrm{SO}_{2}$ is a toxic gas and one of the major components of acid rain [12].

$\mathrm{CO}$ and NOx concentrations in the exhaust gas of syngas fueled engines are significantly lower than gasoline operation [5]. For fuel-rich mixtures, $\mathrm{CO}$ concentration increases steadily with the fuel/air equivalence ratio [13] due to the higher chances of having incomplete combustion [14], while for near-stoichiometric combustion, NOx formation reaches its peak [13] along with the highest combustion temperature [14].

Another major global problem is $\mathrm{CO}_{2}$ emissions. Even if $\mathrm{CO}_{2}$ concentration in the exhaust gas of an engine is higher when gasoline is replaced with syngas [5], biomass gasification can contribute to a reduction in $\mathrm{CO}_{2}$ emissions [15], because it is a carbon neutral energy source [16]. Furthermore, biomass gasification is considered a carbonnegative technology thanks to the co-production of biochar [17]. Biochar is a carbonaceous residue of gasification. It is highly recalcitrant, remaining stable for decades, and when used as soil amendment, can increase crop productivity [17], soil organic matter, microbial activity, and water retention while decreasing fertilizer needs and erosion [18].

Modern engines offer various strategies to reduce pollutants and $\mathrm{CO}_{2}$ emissions such as exhaust gas recirculation or double and ducted fuel injection [19,20]. However, there are several applications where these kinds of approaches are not always possible, such as in the case of water pumps for irrigation, combined heat and power (CHP) systems based on old engine architectures, and portable and emergency generators. In these cases, a successful retrofitting of their performances could happen through a change of their fuel, from fossil-based to bio-based such as syngas from biomass gasification.

In this work, the exhaust gas emissions of two syngas-fueled micro-scale generators were measured. The first one was the commercial biomass gasifier genset system manufactured by All Power Labs (APL PP30). This genset was equipped with a three-way catalyst that was removed to compare the exhaust emissions from this study with those measured in a previous experimental campaign described in [21]. In the second syngas-fueled microscale generator, the engine emissions were measured both running on gasoline and on syngas. In this last configuration, the engine was coupled with a tabletop gasifier prototype to test a possible single system, extremely cheap and compact, made of a gas generation unit and a portable power unit.

During the gasoline operation, the fuel/air equivalence ratio was delivered by the carburetor; while running on syngas the fuel/air equivalence ratio was manually controlled through a gate valve [22]. Different fuel/air ratios were tested to evaluate the effect on the emissions for syngas combustion and to assess the best configuration.

This is not the first comparison between gasoline and syngas in a spark-ignition engine [5], but this time, not only were the emission concentrations compared to each other but also their cumulative amount considering the exhaust volume flows. The cumulative amount is crucial because different fuels lead to different exhaust gas flows at the same power output and, therefore, comparing just the emission concentration does not provide enough information about the evaluation of the environmental impact. The exhaust gas flows were estimated knowing syngas and gasoline combustion stoichiometry.

\section{Materials and Methods}

\subsection{APL PP30}

Exhaust emissions of the APL PP30 (Figure 1) were measured and compared with the results obtained in a previous experimental campaign with the same power plant described in [21], with the difference being that in the previous trial a three-way catalyst was installed in the exhaust line. This device can simultaneously control $\mathrm{CO}, \mathrm{NOx}$, and hydrocarbon 
emissions [23]. This comparison was carried out to get an idea of how much a catalyst could improve the emission performances of an engine running on syngas.

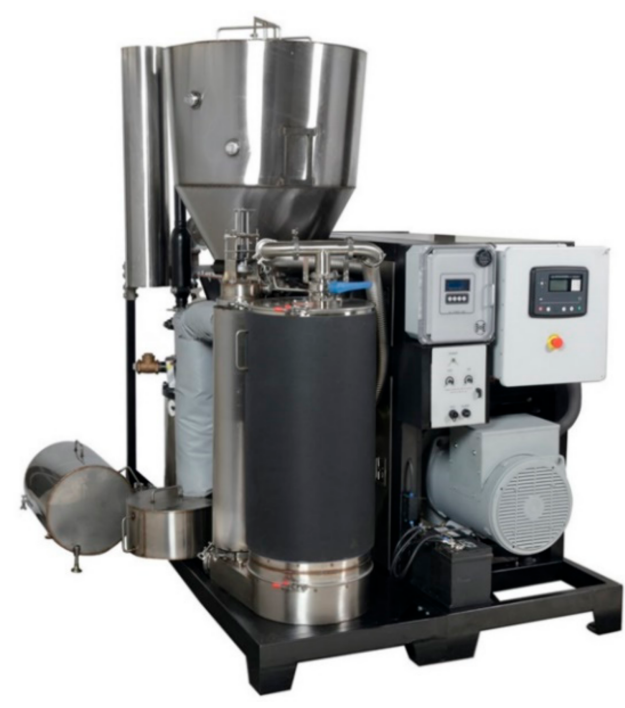

Figure 1. APL PP30 [24].

The APL PP30 consists of a multistage heat recycling downdraft gasifier, a $4.0 \mathrm{~L}$, spark-ignition, Ashok Leyland engine (compression ratio = 12:1), and a filtration stage. The nominal performances of the systems are an electrical power output on-grid of $27 \mathrm{~kW}$ at $60 \mathrm{~Hz}$ and a biomass specific consumption of $1 \mathrm{~kg} / \mathrm{kWh}$ (dry basis) [24].

The biomass used during the test was vine pruning pellets. The gasifier was started up and the syngas was burnt in the flare until the proper temperatures inside the reactor were reached, then it was sent to the engine. An MRU Vario Plus Industrial gas analyzer was used to measure oxygen, carbon monoxide, nitrogen oxide, and sulfur dioxide contents in the engine exhaust gas. This analyzer complies with USEPA methods CTM-030 and CTM-034 and international ASTM D6522, and it is certified according to DIN EN 50379-1 and DIN EN 50379-2 [25]. Different fuel/air equivalence ratios were tested while keeping the electrical power output constant, and different power outputs were tested maintaining the same fuel/air equivalence ratio. The MRU analyzer was set to perform a measurement every $2 \mathrm{~s}$, and for every condition at least 10 samples of operation were analyzed. The emissions analyses was compared with the ones obtained in the previous experimental campaign carried out using a three-way catalyst [21].

\subsection{Portable Petrol Generator and Femto Gasifier}

The generator used in the second part of this study was made of a single-cylinder, air-cooled, four-stroke spark-ignition engine coupled with a single-phase alternator manufactured by Zhejiang Anlu Cleaning Machinery Co., Ltd. Its technical data are summarized in Table 1.

Table 1. Generator technical data, model 168F-1 [26,27].

\begin{tabular}{cc}
\hline Parameter & Value \\
\hline Voltage Adjustment & AVR \\
Rated AC & data \\
Power Factor & 1 \\
Frequency & $50 \mathrm{~Hz}$ \\
Max. AC Output & $2.8 \mathrm{~kW}$ \\
Rated AC Output & $2.5 \mathrm{~kW}$ \\
Displacement & $196 \mathrm{cc}$ \\
Measurement & $43 \times 59 \times 44 \mathrm{~cm}$ \\
Compression Ratio & $8.5: 1$ \\
\hline
\end{tabular}


The gasification unit used to provide syngas to the generator was the "Femto Gasifier", a table-top downdraft gasifier designed and developed by the authors at the "Enzo Ferrari" Engineering Department of the University of Modena and Reggio Emilia Figure 2 [22].

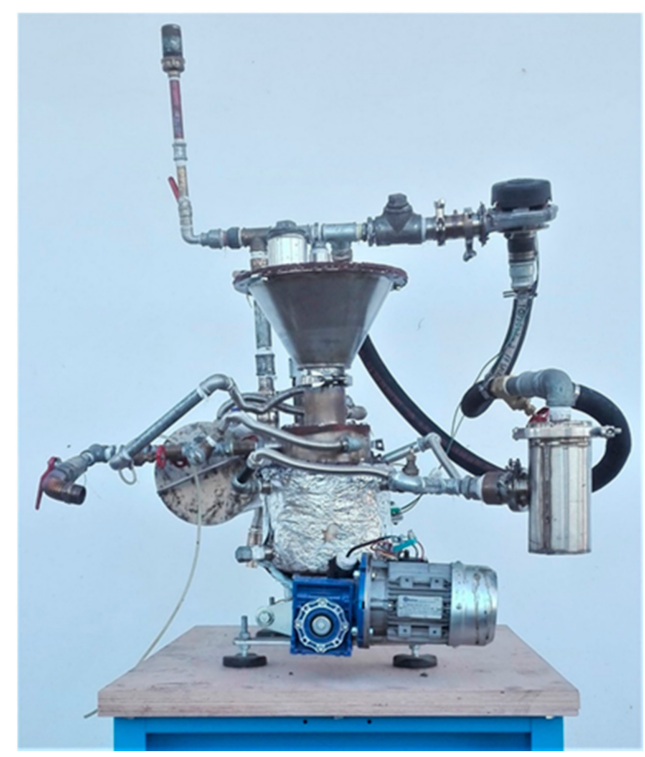

Figure 2. Femto Gasifier [22].

During the current experimental trial, the Femto gasifier was operated with A1 ENplus wood pellets to have a stable gasification process, but it can also be fueled with small wood chips, hemp hurd, and vine pruning pellets [22]. This gasifier was designed to have a nominal biomass flow rate of $2 \mathrm{~kg} / \mathrm{h}$ [6]. In previous experimental campaigns, it has shown a cold gas efficiency near 70\% [22] with an equivalence ratio (the ratio between the air amount entering into the gasifier divided by air amount required for stoichiometric combustion [28]) of 0.24 , and a chemical power output (syngas flow multiplied by its heating value) of around $5.7 \mathrm{~kW}$ [22]. Cold gas efficiency was calculated using Equation (1) [29].

$$
\eta_{\text {gas, cold }}=\frac{\mathrm{HHV}_{\text {syn }} \cdot \dot{\mathrm{V}}_{\text {syn }}}{\mathrm{HHV}_{\mathrm{bio}} \cdot \dot{m}_{\mathrm{bio}}}
$$

where HHV indicates the high heating value; $\dot{\mathrm{V}}_{\text {syn }}$, the volumetric flow of syngas; and $\dot{\mathrm{m}}_{\text {bio, }}$, the mass flow of biomass. It was chosen to measure the emissions with the engine only at idle to have more reproducibility without the risk of instability that can be caused by an excessive demand for gas at a high load. Furthermore, the emissions analysis carried out on the APL PP30 (both with and without the catalyst) did not show significant changes by varying the power output, while even small variations in the fuel/air ratio led to very different results.

Firstly, the engine of the portable generator runs on gasoline at idle. The same emissions analyzer instrument described in the previous paragraph was used. The fuel tank was weighed before and after the runs to measure the fuel consumption. In this way, it was possible to calculate the chemical energy consumption (CEC) knowing the higher heating value of gasoline $\left(\mathrm{HHV}_{\text {gasoline }}=46.88 \mathrm{MJ} / \mathrm{kg}[30]\right)$.

$$
\mathrm{CEC}=\mathrm{HHV}_{\text {fuel }} \cdot \mathrm{m}_{\text {fuel }}
$$

Through the chemical formula of gasoline $\left(\mathrm{C}_{6.97} \mathrm{H}_{14.02}\right.$ [31]), it was possible to estimate the exhaust mass flow and its composition considering stoichiometric combustion and knowing the molar mass (M) of carbon (12.01 g/mol [32]), hydrogen (1.008 g/mol [32], oxygen (15.999 g/mol [32]), nitrogen (14.007 g/mol [32]), and argon (39.95 g/mol [32]). In this way, it was also possible to assess the absolute amount of $\mathrm{CO}_{2}$ and other pollutants 
released in the atmosphere through gasoline combustion and not only their concentration in the exhaust flow. This analytical calculation is summarized as follows.

$$
\begin{gathered}
\mathrm{M}_{\text {gas }}=\mathrm{M}_{\mathrm{C}} \cdot 6.97+\mathrm{M}_{\mathrm{H}} \cdot 14.02=97.842 \mathrm{~g} / \mathrm{mol} \\
\mathrm{mf}_{\mathrm{H} \text { in gas }}=\frac{\mathrm{M}_{\mathrm{H}} \cdot 14.02}{\mathrm{M}_{\text {gas }}}=14.4 \% \\
\mathrm{mf}_{\mathrm{C} \text { in gas }}=\frac{\mathrm{M}_{\mathrm{C}} \cdot 6.97}{\mathrm{M}_{\text {gas }}}=85.6 \%
\end{gathered}
$$

where $\mathrm{mf}$ indicates the mass fraction of the considered element in the gasoline. The $\mathrm{CO}_{2}$ number of moles (n) obtained burning $1 \mathrm{~kg}$ of gasoline (gas) was calculated with Equation (6).

$$
\mathrm{n}_{\mathrm{CO}_{2} \text { per kg of gas }}=\frac{1000 \mathrm{~g} \cdot \mathrm{mf}_{\mathrm{C}} \text { in gas }}{\mathrm{M}_{\mathrm{C}}}=71.23 \mathrm{~mol}_{\mathrm{CO}_{2}} / \mathrm{kg}_{\text {gas }}
$$

Therefore, the mass $(\mathrm{m})$ of $\mathrm{CO}_{2}$ released in the atmosphere burning $1 \mathrm{~kg}$ of gasoline can be obtained with Equation (7):

$$
\mathrm{m}_{\mathrm{CO}_{2} \text { per kg of gas }}=\frac{\mathrm{n}_{\mathrm{CO}_{2} \text { per kg of gas }} \cdot\left(\mathrm{M}_{\mathrm{C}}+2 \cdot \mathrm{M}_{\mathrm{O}}\right)}{1000 \mathrm{~g} / \mathrm{kg}}=3.13 \mathrm{~kg}_{\mathrm{CO}_{2}} / \mathrm{kg}_{\text {gas }}
$$

In a similar way, number of moles and mass of water $\left(\mathrm{H}_{2} \mathrm{O}\right)$ released together with $\mathrm{CO}_{2}$ were obtained with Equations (8) and (9).

$$
\begin{gathered}
\mathrm{n}_{\mathrm{H}_{2} \mathrm{O} \text { per kg of gas }}=\frac{1000 \mathrm{~g} \cdot \mathrm{mf}_{\mathrm{H} \text { in gas }}}{2 \cdot \mathrm{M}_{\mathrm{H}}}=71.65 \mathrm{~mol}_{\mathrm{H}_{2} \mathrm{O}} / \mathrm{kg}_{\text {gas }} \\
\mathrm{m}_{\mathrm{H}_{2} \mathrm{O} \text { per kg of gas }}=\frac{\mathrm{n}_{\mathrm{H}_{2} \mathrm{O} \text { per kg of gas }} \cdot\left(\mathrm{M}_{\mathrm{O}}+2 \cdot \mathrm{M}_{\mathrm{H}}\right)}{1000 \mathrm{~g} / \mathrm{kg}}=1.29 \mathrm{~kg}_{\mathrm{H}_{2} \mathrm{O}} / \mathrm{kg}_{\text {gas }}
\end{gathered}
$$

The number of moles of oxygen necessary to completely burn $1 \mathrm{~kg}$ of gasoline were calculated with Equation (10):

$$
\mathrm{n}_{\mathrm{O}_{2} \text { per kg of gas }}=\mathrm{n}_{\mathrm{CO}_{2} \text { per kg of gas }}+\frac{\mathrm{n}_{\mathrm{H}_{2} \mathrm{O} \text { per kg of gas }}}{2}=107.05 \mathrm{molO}_{2} / \mathrm{kg}_{\text {gas }}
$$

Considering the air to be dry with $78.1 \% \mathrm{~N}_{2}, 20.9 \% \mathrm{O}_{2}$ and $1 \% \mathrm{Ar}$ (by volume), the amount of nitrogen and argon in the exhaust gas flow can be calculated as:

$$
\begin{gathered}
\mathrm{m}_{\mathrm{N}_{2} \text { per kg of gas }}=\frac{\mathrm{n}_{\mathrm{O}_{2} \text { per kg of gas }} \cdot 78.1 \% \cdot \mathrm{M}_{\mathrm{N}_{2}}}{20.9 \% \cdot 1000 \mathrm{~g} / \mathrm{kg}}=11.209 \mathrm{~kg}_{\mathrm{N}_{2}} / \mathrm{kg}_{\text {gas }} \\
\mathrm{m}_{\text {Ar per kg of gas }}=\frac{\mathrm{n}_{\mathrm{O}_{2} \text { per kg of gas }} \cdot 1 \% \cdot \mathrm{M}_{\mathrm{Ar}}}{20.9 \% \cdot 1000 \mathrm{~g} / \mathrm{kg}}=0.205 \mathrm{~kg} \mathrm{Ar}_{\mathrm{Ar}} / \mathrm{kg}_{\text {gas }}
\end{gathered}
$$

The total amount of exhaust gas (exh) produced from burning $1 \mathrm{~kg}$ of gasoline was calculated as the sum of nitrogen and argon of the comburent air and $\mathrm{CO}_{2}$ and water produced through the combustion of gasoline:

$\mathrm{m}_{\text {exh per kg of gas }}=\mathrm{m}_{\mathrm{CO}_{2}}$ per kg of gas $+\mathrm{m}_{\mathrm{H}_{2} \mathrm{O} \text { per kg of gas }}+\mathrm{m}_{\mathrm{N}_{2} \text { per kg of gas }}+\mathrm{m}_{\mathrm{Ar} \text { per kg of gas }}=15.839 \mathrm{~kg}_{\text {exh }} / \mathrm{kg}_{\text {gas }}$

The volume $(\mathrm{V})$ of the exhaust per $\mathrm{kg}$ of gasoline at a certain temperature can be calculated knowing the density $(\rho)$ of the various components at that temperature (Table 2). The temperature of $500 \mathrm{~K}$ for the exhaust was chosen for the comparison between syngas and gasoline combustion. 


$$
\begin{aligned}
\mathrm{V}_{\text {exh@500K per kg of gas }} & =\frac{\mathrm{m}_{\mathrm{CO}_{2} \text { per kg of gas }}}{\rho_{\mathrm{CO}_{2} @ 500 \mathrm{~K}}}+\frac{\mathrm{m}_{\mathrm{H}_{2} \mathrm{O} \text { per kg of gas }}}{\rho_{\mathrm{H}_{2} \mathrm{O} @ 500 \mathrm{~K}}}+\frac{\mathrm{m}_{\mathrm{N}_{2}} \text { per kg of gas }}{\rho_{\mathrm{N}_{2} @ 500 \mathrm{~K}}}+\frac{\mathrm{m}_{\mathrm{Ar}} \text { per kg of gas }}{\rho_{\mathrm{Ar} @ 500 \mathrm{~K}}} \\
& =22.733 \mathrm{~m}_{\text {exh }}^{3} / \mathrm{kg}_{\text {gas }}
\end{aligned}
$$

Table 2. Densities considered in the analytical calculations at 1 atm $[33,34]$.

\begin{tabular}{cc}
\hline Density & Value \\
\hline$\rho_{\mathrm{CO} 2 @ 500 \mathrm{~K}}$ & $1.0594 \mathrm{~kg} / \mathrm{m}^{3}$ \\
$\rho_{\mathrm{H} 2 @ 500 \mathrm{~K}}$ & $0.4405 \mathrm{~kg} / \mathrm{m}^{3}$ \\
$\rho_{\mathrm{N} 2 @ 500 \mathrm{~K}}$ & $0.6739 \mathrm{~kg} / \mathrm{m}^{3}$ \\
$\rho_{\mathrm{Ar} @ 500 \mathrm{~K}}$ & $0.974 \mathrm{~kg} / \mathrm{m}^{3}$ \\
$\rho_{\mathrm{CO} 2 @ 300 \mathrm{~K}}$ & $1.773 \mathrm{~kg} / \mathrm{m} 3$ \\
$\rho_{\mathrm{N} 2 @ 300 \mathrm{~K}}$ & $1.1233 \mathrm{~kg} / \mathrm{m}^{3}$ \\
$\rho_{\mathrm{H} 2 @ 300 \mathrm{~K}}$ & $0.08078 \mathrm{~kg} / \mathrm{m}^{3}$ \\
$\rho_{\mathrm{CO} 300 \mathrm{~K}}$ & $1.1233 \mathrm{~kg} / \mathrm{m}^{3}$ \\
$\rho_{\text {air@300K }}$ & $1.1614 \mathrm{~kg} / \mathrm{m}^{3}$ \\
$\rho_{\mathrm{CH} 4 @ 300 \mathrm{~K}}$ & $0.65171 \mathrm{~kg} / \mathrm{m}^{3}$ \\
\hline
\end{tabular}

${ }^{1} \rho_{\mathrm{CH} 4 @ 300 \mathrm{~K}}=\mathrm{P} /(\mathrm{RT})=101,325 \mathrm{~Pa} /(518.251(\mathrm{~J} / \mathrm{kgK}) \cdot 300 \mathrm{~K})$ [35].

Knowing both the exhaust volume and the $\mathrm{CO}_{2}$ volume released per $\mathrm{kg}$ of gasoline, the volumetric concentration (x) of $\mathrm{CO}_{2}$ in the exhaust can be obtained with Equation (15).

$$
\mathrm{x}_{\mathrm{CO}_{2} \text {, exh }}=\frac{\mathrm{m}_{\mathrm{CO}_{2} \text { per kg of gas }} / \rho_{\mathrm{CO}_{2} @ 500 \mathrm{~K}}}{\mathrm{~V}_{\text {exh@500K per kg of gas }}}
$$

Once the emissions were measured, they were correlated to the absolute amount of exhaust gases released during the combustion in the engine knowing the fuel consumption. After that, the test with syngas was set up adapting the generator to be coupled with the gasifier as described in [22]. A wideband $\mathrm{O}_{2}$ sensor was implemented on the exhaust pipe to manually adjust the fuel/air ratio of the mixture through a gate valve added at the intake manifold. The original air filter was removed and substituted with an Iveco air filter for trucks to preserve the engine from tars and particulate without excessive pressure drop. It is important to prevent an excessive amount of these contaminants from reaching the engine to maintain the operation and endurance of components such as valves, combustion chamber, and pistons [36]. Tar yield depends on the gasifier type [37] and the downdraft reactors produce syngas with a low tar content $[38,39]$ and, therefore, was chosen to implement this very simple filtration stage. The fuel tank was removed from the generator for safety reasons. Four thermocouples were used to measure the following temperature: reactor grate, syngas downstream the reactor, exhaust gas flow, and ambient air. A G4-grade gas totalizer was used to measure the airflow entering the gasifier as a gasifying agent. A differential manometer was used to measure the pressure drop across the reactor. The scheme of the gasifier engine system is depicted in Figure 3. 


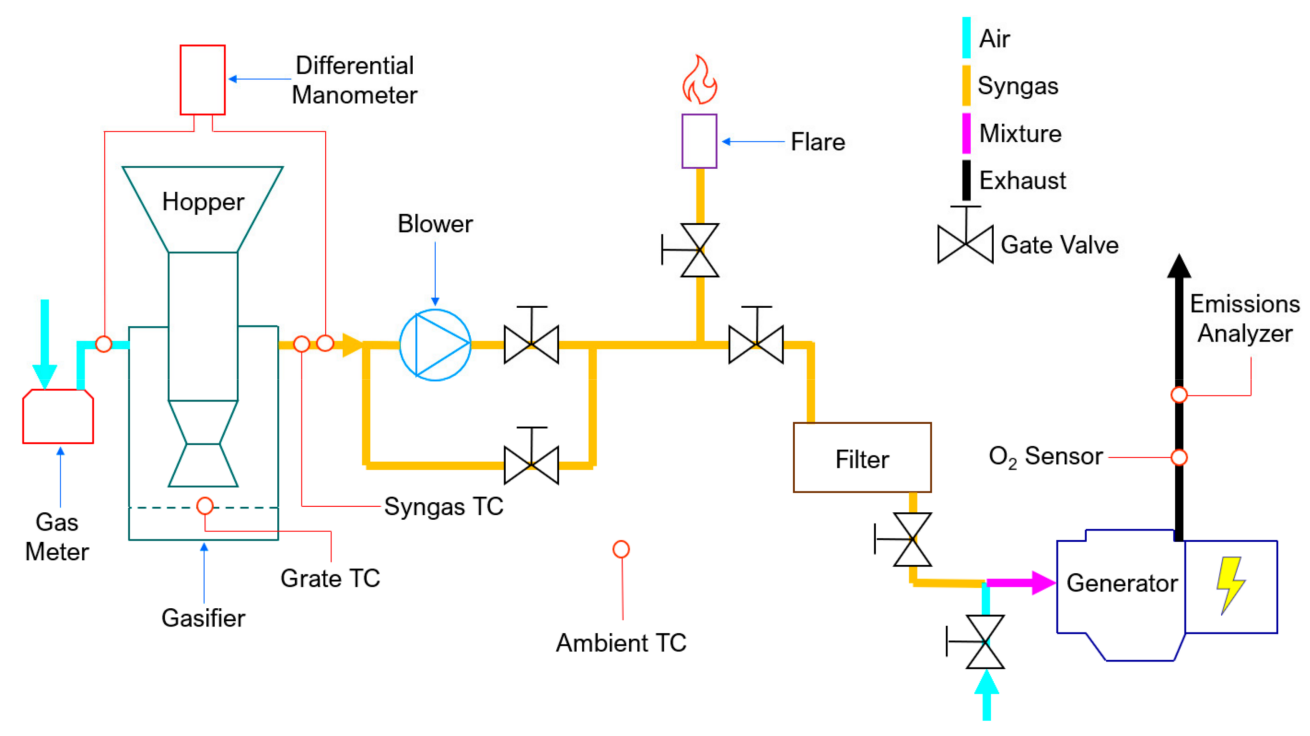

Figure 3. Scheme of the experimental apparatus, picture adapted from [22].

The gasifier was started up and the syngas was burnt in the flare until the proper conditions of temperature and pressure drop were reached, then the instrument was placed at the outlet of the exhaust pipe of the generator and the engine was turned on, operating on syngas. Different fuel/air ratios were tested and monitored with the emissions analyzer and 10 or more samples were analyzed for each configuration, always at idle. Knowing the airflow entering the gasifier, it was possible to estimate the syngas flow going to the engine with Equation (16) [40]:

$$
\dot{\mathrm{V}}_{\text {syn }}=\frac{\left(\dot{\mathrm{V}}_{\text {gasification air }}\right)\left(\mathrm{x}_{\mathrm{N}_{2}, \text { air }}\right)}{\mathrm{x}_{\mathrm{N}_{2}, \text { syn }}}
$$

The following assumptions were made:

- Air was considered dry with $78.1 \% \mathrm{~N}_{2}, 20.9 \% \mathrm{O}_{2}$, and $1 \% \mathrm{Ar}$;

- Syngas was considered dry and without molecular oxygen.

The considered syngas composition is shown in Table 3.

Table 3. Syngas composition considered in the test.

\begin{tabular}{cccccc}
\hline $\mathbf{x}_{\mathbf{H} 2 \text {,syn }}$ & $\mathbf{x}_{\mathrm{N} 2 \text {,syn }}$ & $\mathbf{x}_{\mathbf{C H} 4 \text {,syn }}$ & $\mathbf{x}_{\mathbf{C O}, \text { syn }}$ & $\mathbf{x}_{\mathbf{C O} 2 \text {,syn }}$ & $\mathbf{H H V}_{\text {syn }}$ \\
\hline $15.7 \%$ & $51.4 \%$ & $1.4 \%$ & $18.9 \%$ & $12.6 \%$ & $4.9 \mathrm{MJ} / \mathrm{m}^{3}$ \\
\hline
\end{tabular}

The composition previously obtained in [22] was used in this work. All the gas analyses performed on syngas produced with the Femto gasifier running on A1-grade pellets showed a quite stable gas composition, with typical values of downdraft gasifier [41-43] and, therefore, using this composition was considered quite reliable.

Through Equation (2), it was also possible to calculate the chemical energy consumption running on syngas. As previously done in the test with gasoline, the exhaust flow was analytically calculated knowing syngas flow and composition with the following equations, considering again a stoichiometric combustion. In this way, it is possible to make a comparison of the cumulative emissions released during the combustion (XY indicates the generic component).

$$
\dot{\mathrm{V}}_{\mathrm{XY}, \mathrm{syn}}=\left(\mathrm{x}_{\mathrm{XY}, \mathrm{syn}}\right) \dot{\mathrm{V}}_{\mathrm{syn}}
$$

$$
\dot{\mathrm{m}}_{\mathrm{syn}}=\dot{\mathrm{V}}_{\mathrm{H}_{2}, \mathrm{syn}} \cdot \rho_{\mathrm{H}_{2} @ 300 \mathrm{~K}}+\dot{\mathrm{V}}_{\mathrm{N}_{2}, \mathrm{syn}} \cdot \rho_{\mathrm{N}_{2} @ 300 \mathrm{~K}}+\dot{\mathrm{V}}_{\mathrm{CO}_{2}, \mathrm{syn}} \cdot \rho_{\mathrm{CO}_{2} @ 300 \mathrm{~K}}+\dot{\mathrm{V}}_{\mathrm{CO}, \mathrm{syn}} \cdot \rho_{\mathrm{CO} @ 300 \mathrm{~K}}+\mathrm{V}_{\mathrm{CH}_{4}, \mathrm{syn}} \cdot \rho_{\mathrm{CH}_{4} @ 300 \mathrm{~K}}
$$


For syngas components and air, the density was considered at $300 \mathrm{~K}$ because this was the average ambient value recorded during the test.

$$
\begin{aligned}
& \dot{\mathrm{V}}_{\mathrm{O}_{2} \text {,air }}=\frac{\dot{\mathrm{V}}_{\mathrm{H}_{2, \mathrm{syn}}}}{2}+\frac{\dot{\mathrm{V}}_{\mathrm{CO}, \mathrm{syn}}}{2}+2\left(\dot{\mathrm{V}}_{\mathrm{CH}_{4}, \mathrm{syn}}\right) \\
& \dot{\mathrm{V}}_{\mathrm{N}_{2}, \mathrm{air}}=\left(\mathrm{x}_{\mathrm{N}_{2}, \mathrm{air}}\right) \frac{\dot{\mathrm{V}}_{\mathrm{O}_{2} \text {,air }}}{\mathrm{x}_{\mathrm{O}_{2} \text {, air }}} \\
& \dot{\mathrm{V}}_{\mathrm{Ar}, \mathrm{air}}=\dot{\mathrm{V}}_{\mathrm{Ar}, \mathrm{exh}}=\left(\mathrm{x}_{\mathrm{Ar}, \text { air }}\right) \frac{\dot{\mathrm{V}}_{\mathrm{O}_{2, \text { air }}}}{\mathrm{x}_{\mathrm{O}_{2} \text {, air }}} \\
& \dot{\mathrm{m}}_{\mathrm{air}}=\left(\dot{\mathrm{V}}_{\mathrm{O}_{2}, \text { air }}+\dot{\mathrm{V}}_{\mathrm{N}_{2}, \text { air }}+\dot{\mathrm{V}}_{\mathrm{N}_{2} \text {,air }}\right) \rho_{\mathrm{air} @ 300 \mathrm{~K}} \\
& \dot{\mathrm{m}}_{\mathrm{exh}}=\dot{\mathrm{m}}_{\mathrm{air}}+\dot{\mathrm{m}}_{\mathrm{syn}} \\
& \dot{\mathrm{V}}_{\mathrm{N}_{2}, \mathrm{exh}}=\dot{\mathrm{V}}_{\mathrm{N}_{2} \text {,syn }}+\dot{\mathrm{V}}_{\mathrm{N}_{2} \text {, air }} \\
& \dot{\mathrm{V}}_{\mathrm{H}_{2} \mathrm{O}, \mathrm{exh}}=\dot{\mathrm{V}}_{\mathrm{H}_{2}, \mathrm{syn}}+2\left(\dot{\mathrm{V}}_{\mathrm{CH}_{4}, \mathrm{syn}}\right) \\
& \dot{\mathrm{V}}_{\mathrm{CO}_{2}, \mathrm{exh}}=\dot{\mathrm{V}}_{\mathrm{CO}, \mathrm{syn}}+\dot{\mathrm{V}}_{\mathrm{CO}_{2}, \mathrm{syn}} \\
& \mathrm{x}_{\mathrm{XY}, \mathrm{exh}}=\frac{\dot{\mathrm{V}}_{\mathrm{XY}, \mathrm{exh}}}{\dot{\mathrm{V}}_{\mathrm{N}_{2}, \mathrm{exh}}+\dot{\mathrm{V}}_{\mathrm{H}_{2} \mathrm{O}, \mathrm{exh}}+\dot{\mathrm{V}}_{\mathrm{CO}_{2}, \mathrm{exh}}+\dot{\mathrm{V}}_{\mathrm{Ar}, \mathrm{exh}}} \\
& \dot{\mathrm{V}}_{\mathrm{exh} @ 500 \mathrm{~K}}=\frac{\dot{\mathrm{m}}_{\mathrm{exh}}}{\mathrm{x}_{\mathrm{N}_{2}, \mathrm{exh}} \cdot \rho_{\mathrm{N}_{2} @ 500 \mathrm{~K}}+\mathrm{x}_{\mathrm{H}_{2} \mathrm{O}, \mathrm{exh}} \cdot \rho_{\mathrm{H}_{2} \mathrm{O} @ 500 \mathrm{~K}}+\mathrm{x}_{\mathrm{CO}_{2}, \text { exh }} \cdot \rho_{\mathrm{CO}_{2} @ 500 \mathrm{~K}}+\mathrm{x}_{\mathrm{Ar}, \mathrm{exh}} \cdot \rho_{\mathrm{Ar} @ 500 \mathrm{~K}}} \\
& \dot{\mathrm{m}}_{\mathrm{CO}_{2}, \mathrm{exh}}=\dot{\mathrm{V}}_{\mathrm{exh} @ 500 \mathrm{~K}} \times \mathrm{x}_{\mathrm{CO}_{2}, \mathrm{exh}} \times \rho_{\mathrm{CO}_{2} @ 500 \mathrm{~K}}
\end{aligned}
$$

\section{Results and Discussion}

The format of emission results is the following:

- (Average result \pm Standard deviation) if the result is a percentage.

- (Average result \pm Relative standard deviation) for the others.

All pollutant concentrations are presented in $\mathrm{mg} / \mathrm{m}^{3}$ and normalized at $13 \%$ oxygen content in the exhaust gas $\left(\mathrm{mg} / \mathrm{m}^{3} @ 13 \% \mathrm{O}_{2}\right)$.

\subsection{APL PP30}

The results of the emissions analysis performed on the PP30 without the catalyst are summarized in Tables 4 and 5 .

Table 4. Ashok without catalyst at $10.8 \mathrm{~kW}$ and various fuel/air ratios.

\begin{tabular}{cccccc}
\hline $\mathbf{N}^{\circ}$ & $\begin{array}{c}\mathbf{O}_{\mathbf{2}} \text { in } \\
\text { Exhaust }[\%]\end{array}$ & $\begin{array}{c}\mathbf{C O} \\
{\left[\mathbf{m g} / \mathbf{m}^{3} @\right.} \\
\left.\mathbf{1 3 \%} \mathbf{O}_{\mathbf{2}}\right]\end{array}$ & $\begin{array}{c}\mathbf{N O} \\
{\left[\mathbf{m g} / \mathbf{m}^{3} @\right.} \\
\left.\mathbf{1 3 \%} \mathbf{O}_{\mathbf{2}}\right]\end{array}$ & $\begin{array}{c}\mathbf{N O x} \\
{\left[\mathbf{m g} / \mathbf{m}^{\mathbf{3}} @\right.} \\
\left.\mathbf{1 3 \%} \mathbf{O}_{\mathbf{2}}\right]\end{array}$ & $\begin{array}{c}\mathbf{S O}_{2} \\
{\left[\mathbf{m g} / \mathbf{m}^{\mathbf{3}} @\right.} \\
\left.\mathbf{1 3 \%} \mathbf{O}_{\mathbf{2}}\right]\end{array}$ \\
\hline 1 & $0.6 \pm /$ & $8400 \pm 6 \%$ & $650 \pm 3 \%$ & $1000 \pm 3 \%$ & n.d. \\
2 & $0.5 \pm /$ & $10,400 \pm 6 \%$ & $633 \pm 1 \%$ & $980 \pm 1 \%$ & n.d. \\
3 & $1.09 \pm 0.09$ & $1427 \pm 0.3 \%$ & $957 \pm 0.7 \%$ & $1480 \pm 0.7 \%$ & n.d. \\
4 & $1.7 \pm 0.1$ & $1350 \pm 1 \%$ & $968 \pm 0.9 \%$ & $1500 \pm 0.8 \%$ & n.d. \\
5 & $2.67 \pm 0.05$ & $1350 \pm 1 \%$ & $941 \pm 0.4 \%$ & $1462 \pm 0.4 \%$ & n.d. \\
6 & $2.54 \pm 0.05$ & $1350 \pm 2 \%$ & $910 \pm 1 \%$ & $1410 \pm 1 \%$ & n.d. \\
\hline
\end{tabular}


Table 5. Ashok without catalyst at stable fuel/air ratio and various power outputs.

\begin{tabular}{|c|c|c|c|c|c|c|}
\hline $\mathbf{N}^{\circ}$ & $\begin{array}{c}\text { El. Power } \\
\text { Output } \\
{[\mathrm{kW}]}\end{array}$ & $\begin{array}{c}\mathrm{O}_{2} \text { in } \\
\text { Exhaust } \\
{[\%]}\end{array}$ & $\begin{array}{c}\mathrm{CO} \\
{\left[\mathrm{mg} / \mathrm{m}^{3} @\right.} \\
\left.13 \% \mathrm{O}_{2}\right]\end{array}$ & $\begin{array}{c}\mathrm{NO} \\
{\left[\mathrm{mg} / \mathrm{m}^{3} @\right.} \\
\left.13 \% \mathrm{O}_{2}\right]\end{array}$ & $\begin{array}{c}\text { NOx } \\
{\left[\mathrm{mg} / \mathrm{m}^{3} @\right.} \\
\left.13 \% \mathrm{O}_{2}\right]\end{array}$ & $\begin{array}{c}\mathrm{SO}_{2} \\
{\left[\mathrm{mg} / \mathrm{m}^{3} @\right.} \\
\left.13 \% \mathrm{O}_{2}\right]\end{array}$ \\
\hline 7 & 6.7 & $1.7 \pm 0.4$ & $1660 \pm 2 \%$ & $594 \pm 1 \%$ & $920 \pm 1 \%$ & n.d. \\
\hline 8 & 8.7 & $1.8 \pm 0.3$ & $1610 \pm 4 \%$ & $680 \pm 2 \%$ & $1050 \pm 2 \%$ & n.d. \\
\hline 9 & 10.0 & $1.2 \pm 0.3$ & $1700 \pm 8 \%$ & $640 \pm 2 \%$ & $990 \pm 2 \%$ & n.d. \\
\hline
\end{tabular}

Table 4 contains the emissions obtained with the electrical power output fixed at $10.8 \mathrm{~kW}$ varying the fuel/air ratio. Table 5 contains the emissions measured when varying the power output and trying to maintain the fuel/air ratio as stable as possible.

The percentage of oxygen contained in the exhaust shown in the second column is a qualitative indicator of the fuel/air ratio, the higher the oxygen content is, the lower the ratio.

It is possible to see that the fuel/air ratio has a great influence on the emission contrary to the power output. As expected, by decreasing the fuel/air ratio, the carbon monoxide decreases as well, while the nitrogen oxides increase. For all the tests, sulfur dioxide was not detected in the exhaust gas. In Table 6, the two best cases, number 6 for the $\mathrm{CO}$ content and number 7 for the NOx content, were compared to the two best cases described in [21] with the same PP30, but with the catalyst.

Table 6. Best performance Ashok with and without catalyst [21].

\begin{tabular}{ccccc}
\hline Test & Catalyst & $\begin{array}{c}\text { El. Power } \\
\text { Output }[\mathbf{k W}]\end{array}$ & $\begin{array}{c}\mathbf{C O} \\
{\left[\mathbf{m g} / \mathbf{m}^{\mathbf{3}} @\right.} \\
\left.\mathbf{1 3} \mathbf{O}_{\mathbf{2}}\right]\end{array}$ & $\begin{array}{c}\mathbf{N O x} \\
{\left[\mathbf{m g} / \mathbf{m}^{\mathbf{3}} @\right.} \\
\left.\mathbf{1 3 \%} \mathbf{O}_{\mathbf{2}}\right]\end{array}$ \\
\hline$[21]$ & On & 13.3 & 3 & 19 \\
{$[21]$} & On & 18.3 & 3 & 19 \\
6 & Off & 10.8 & $1350 \pm 2 \%$ & $1410 \pm 1 \%$ \\
7 & Off & 6.7 & $1660 \pm 2 \%$ & $920 \pm 1 \%$ \\
\hline
\end{tabular}

Emissions with the implementation of a three-way catalyst are between 2 and 3 orders of magnitude lower.

\subsection{Portable Petrol Generator and Femto Gasifier}

\subsubsection{Gasoline and Syngas Analytical Comparison}

Table 7 shows the results obtained through the analytical calculation of mass and volume of the exhaust and its $\mathrm{CO}_{2}$ content considering the gasoline and the syngas consumption measured during the experimental tests at idle.

Table 7. Experimental and analytic results for gasoline and syngas.

\begin{tabular}{ccc}
\hline Fuel & Gasoline & Syngas \\
\hline Fuel consumption & $0.467 \mathrm{~kg} / \mathrm{h}$ & $2.62 \mathrm{~m}^{3} / \mathrm{h}$ \\
$\mathrm{CEC}_{\text {per hour }}$ & $21.88 \mathrm{MJ}$ & $12.97 \mathrm{MJ}$ \\
$\dot{m}_{\text {exh }}$ & $7.39 \mathrm{~kg} / \mathrm{h}$ & $5.64 \mathrm{~kg} / \mathrm{h}$ \\
$\dot{\mathrm{V}}_{\text {exh@500K }}$ & $10.61 \mathrm{~m}^{3} / \mathrm{h}$ & $7.84 \mathrm{~m} / \mathrm{h}$ \\
$\dot{\mathrm{m}}_{\mathrm{CO}_{2}, \text { exh }}$ & $1.46 \mathrm{~kg} / \mathrm{h}$ & $1.47 \mathrm{~kg} / \mathrm{h}$ \\
$\mathrm{x}_{\mathrm{CO}_{2} \text { exh }}$ & $13.02 \%$ & $17.71 \%$ \\
\hline
\end{tabular}

There are three important outcomes from Table 7.

The first outcome is that the energetic consumption running on syngas is considerably lower compared to gasoline (all the tests were carried out at idle). This is in accordance with the higher efficiency measured by [5]. 
The second outcome is the higher mass and volume flow of the exhaust gas running on gasoline. Therefore, even hypothesizing that the emission concentrations in the exhaust gas were the same, the impact on the environment would be lower running on syngas.

The third outcome is that, as measured by [5], the $\mathrm{CO}_{2}$ concentration in the exhaust gas is more than $30 \%$ higher running on syngas. However, considering the total amount of exhaust gas released by the engine, less than $1 \%$ more $\mathrm{CO}_{2}$ is released in the atmosphere. This fact, together with the carbon negativity of the biomass gasification process, makes the higher $\mathrm{CO}_{2}$ concentration irrelevant.

\subsubsection{Gasoline and Syngas Emissions Comparison}

Table 8 summarizes the emissions results of the analyses performed on the generator running on gasoline and running on syngas. The oxygen content shown in the second column can be used as a qualitative indicator of the different fuel/air ratios tested running on syngas. The percentages of oxygen are quite higher compared to the ones measured with the APL PP30, probably due to the different placement of the $\mathrm{O}_{2}$ sensor in the two engines.

Table 8. Gasoline and syngas emissions results.

\begin{tabular}{cccccc}
\hline Fuel & $\begin{array}{c}\mathbf{O}_{\mathbf{2}} \text { in } \\
\text { Exhaust [\%] }\end{array}$ & $\begin{array}{c}\mathbf{C O} \\
{\left[\mathbf{m g} / \mathbf{m}^{\mathbf{3}} @\right.} \\
\left.\mathbf{1 3 \%} \mathbf{O}_{\mathbf{2}}\right]\end{array}$ & $\begin{array}{c}\mathbf{N O} \\
{\left[\mathbf{m g} / \mathbf{m}^{\mathbf{3}} @\right.} \\
\left.\mathbf{1 3 \%} \mathbf{O}_{\mathbf{2}}\right]\end{array}$ & $\begin{array}{c}\mathbf{N O x} \\
{\left[\mathbf{m g} / \mathbf{m}^{3} @\right.} \\
\left.\mathbf{1 3 \%} \mathbf{O}_{\mathbf{2}}\right]\end{array}$ & $\begin{array}{c}\mathbf{S O}_{\mathbf{2}} \\
{\left[\mathbf{m g}_{\mathbf{3}} \mathbf{3} @\right.} \\
\left.\mathbf{1 3} \% \mathbf{O}_{\mathbf{2}}\right]\end{array}$ \\
\hline Gasoline & $8.93 \pm 0.09$ & $24,700 \pm 3 \%$ & $45.4 \pm 2 \%$ & $69.7 \pm 1 \%$ & $50 \pm 60 \%$ \\
Syngas & $8.5 \pm 0.1$ & $14,000 \pm 20 \%$ & $22.8 \pm 3 \%$ & $35 \pm 3 \%$ & n.d. \\
Syngas & $8.8 \pm 0.1$ & $3100 \pm 30 \%$ & $24 \pm 5 \%$ & $38 \pm 5 \%$ & n.d. \\
Syngas & $9.12 \pm 0.09$ & $1250 \pm 3 \%$ & $21.0 \pm 3 \%$ & $32 \pm 3 \%$ & n.d. \\
Syngas & $10.1 \pm 0.1$ & $1120 \pm 5 \%$ & $16.6 \pm 5 \%$ & $25.6 \pm 3 \%$ & n.d. \\
Syngas & $10.8 \pm 0.2$ & $1700 \pm 11 \%$ & $15.9 \pm 2 \%$ & $24.6 \pm 2 \%$ & n.d. \\
Syngas & $11.4 \pm 0.5$ & $4000 \pm 30 \%$ & $16.8 \pm 5 \%$ & $26 \pm 6 \%$ & n.d. \\
\hline
\end{tabular}

The CO emissions released running on syngas are similar to the ones of the APL PP30 considering the best configurations, while the nitrogen oxides are always around one order of magnitude lower compared to the APL PP30. This can be due to a lower compression ratio [44] of the portable generator (8.5:1 [27]) compared to the Ashok Leyland engine [24].

Concerning syngas and gasoline comparison, the emissions released running on syngas are much lower than the ones running on gasoline for all the tested fuel/air ratios. In particular, considering the best performances, the $\mathrm{CO}$ content is about 20 times lower, while the nitrogen oxides are almost one third running on syngas when compared to gasoline.

Very similar ratios between gasoline and syngas emissions were measured by [5] during their test at the lowest power output (about $740 \mathrm{~W}$ ).

Even with the syngas from Femto gasifier, no sulfur dioxides were detected unlike the operation with gasoline.

Results concerning only CO and NOx are also depicted in Figure 4.

The error bars in the graph show a great uncertainty, calculated as standard deviation, when the syngas emissions are higher. This can be due to combustion instability, while when the emissions are low, they are also quite stable.

Gasoline emissions, even if they are much higher than syngas, are also quite stable.

Furthermore, considering the analytical calculation, not only does the exhaust gas running on syngas contain a much lower amount of pollutants, but it is also about one-third less. Therefore, the difference between the cumulative amounts of pollutants released in the atmosphere is even higher than the difference shown by the emission concentrations. 


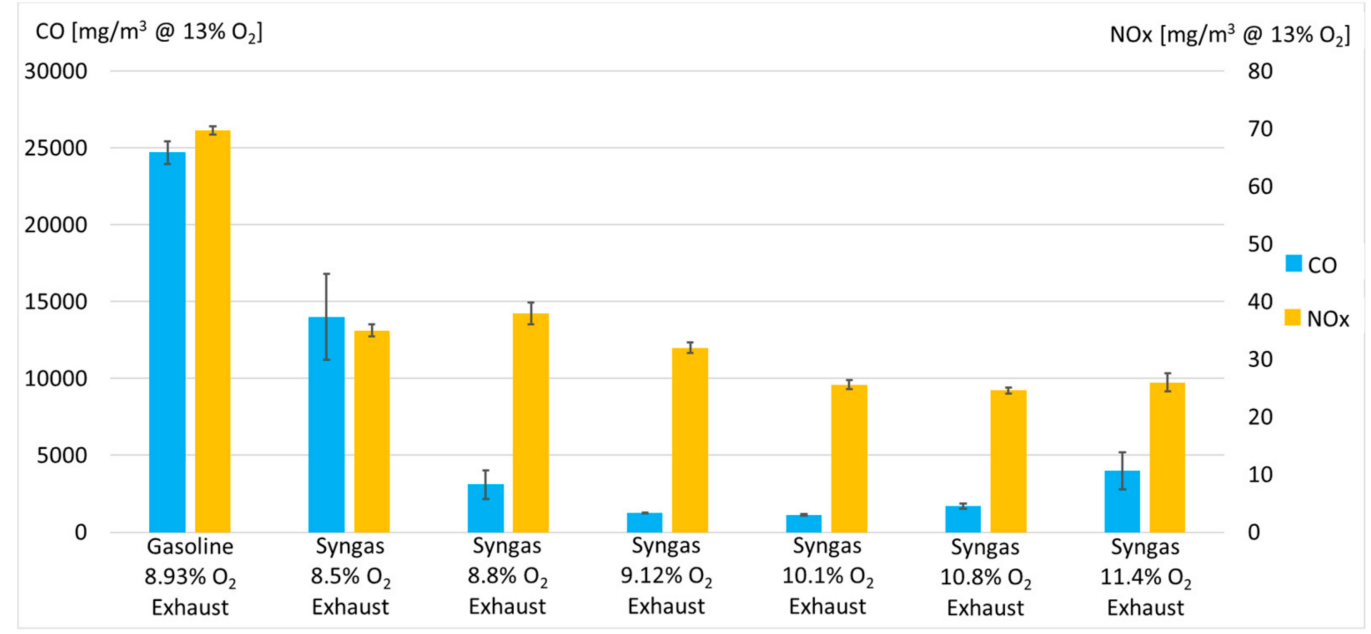

Figure 4. $\mathrm{CO}$ and NOx concentrations for gasoline and syngas at different fuel/air ratios.

\section{Conclusions}

In this study, the emissions of two engines running on syngas were analyzed compared with the emissions obtained running on gasoline and the effect of a three-way catalyst was assessed. Emissions are usually expressed as a concentration. Therefore, for a better evaluation, the total amount of exhaust gas released with the two different fuels was calculated. The results showed a much lower pollutant concentration using syngas compared to gasoline. In particular, considering the best configurations, every cubic meter of exhaust gas released running on syngas contains about 20 times less $\mathrm{CO}$ and almost one-third of nitrogen oxides compared to gasoline. Furthermore, no sulfur dioxides were detected running on syngas as opposed to gasoline. In addition, both volume and mass flow of the exhaust gas was about $25 \%$ lower with syngas, further increasing the gap between the pollutant cumulative amounts released in the atmosphere running on syngas and gasoline.

Finally, to obtain a very clean exhaust gas, a three-way catalyst can be used. The tests showed that it can allow a reduction between 2 and 3 orders of magnitude of the pollutant's concentration. These results, together with the carbon negativity of the biomass gasification process, make the replacement of gasoline with syngas from biomass gasification in sparkignition engines very attractive. Running on syngas can significantly and immediately improve the GHG and pollutant emissions of various applications like irrigation, CHP systems based on old engine architectures, and portable and emergency generators.

The next step would be to measure the engine airflow in order to assess the fuel/air ratio that guarantees the best performances and evaluate it at different electrical power outputs as well as analyze the in-cylinder pressure for a better understanding of the combustion process [45].

Author Contributions: Conceptualization, M.P.; methodology, M.P. and N.M.; investigation, M.P. and N.M.; data curation, M.P.; writing—original draft preparation, M.P. and G.A.; writing—review and editing, N.M. and S.P.; visualization, G.A. and S.P.; supervision, P.T. and A.M.; All authors have read and agreed to the published version of the manuscript.

Funding: This research received no external funding.

Institutional Review Board Statement: Not applicable.

Informed Consent Statement: Not applicable.

Data Availability Statement: Not applicable.

Conflicts of Interest: The authors declare no conflict of interest. 


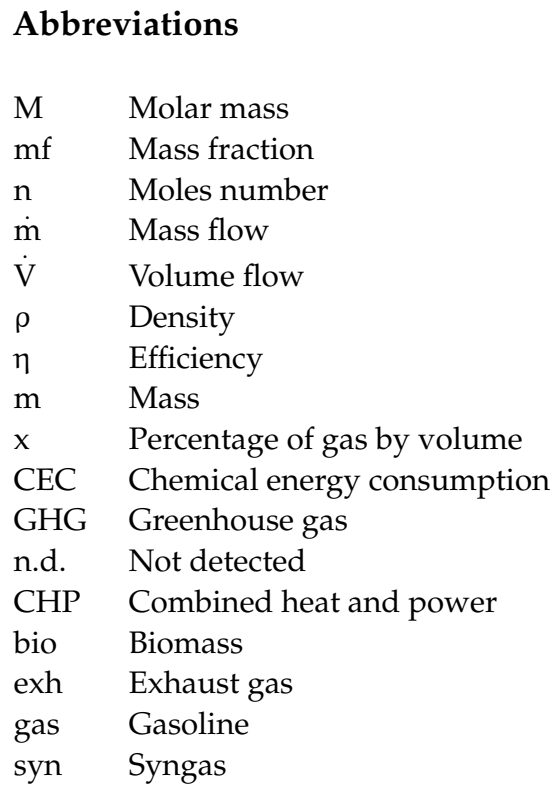

\section{References}

1. Gatto, F.; Re, I. Circular Bioeconomy Business Models to Overcome the Valley of Death. A Systematic Statistical Analysis of Studies and Projects in Emerging Bio-Based Technologies and Trends Linked to the SME Instrument Support. Sustain. J. Rec. 2021, 13, 1899. [CrossRef]

2. Chaves, L.I.; Da Silva, M.J.; De Souza, S.N.M.; Secco, D.; Rosa, H.A.; Nogueira, C.E.C.; Frigo, E.P. Small-scale power generation analysis: Downdraft gasifier coupled to engine generator set. Renew. Sustain. Energy Rev. 2016, 58, 491-498. [CrossRef]

3. Alsaleh, M.; Abdulwakil, M.; Abdul-Rahim, A. Does Social Businesses Development Affect Bioenergy Industry Growth under the Pathway of Sustainable Development? Sustain. J. Rec. 2021, 13, 1989. [CrossRef]

4. Hoque, E.; Rashid, F.; Aziz, M. Gasification and Power Generation Characteristics of Rice Husk, Sawdust, and Coconut Shell Using a Fixed-Bed Downdraft Gasifier. Sustain. J. Rec. 2021, 13, 2027. [CrossRef]

5. Shah, A.; Srinivasan, R.; To, S.D.F.; Columbus, E.P. Performance and emissions of a spark-ignited engine driven generator on biomass based syngas. Bioresour. Technol. 2010, 101, 4656-4661. [CrossRef] [PubMed]

6. Puglia, M.; Morselli, N.; Tartarini, P. Design and First Tests of a Lab Scale (2KG/H) Gasifier. In Proceedings of the 27th European Biomass Conference and Exhibition, EUBCE 2019, Lisbon, Portugal, 27-30 May 2019; ETA-Florence Renewable Energies: Florence, Italy, 2019; pp. 797-801. [CrossRef]

7. Rasmussen, N.B.; Aryal, N. Syngas production using straw pellet gasification in fluidized bed allothermal reactor under different temperature conditions. Fuel 2020, 263, 116706. [CrossRef]

8. Kul, B.S.; Kahraman, A. Energy and Exergy Analyses of a Diesel Engine Fuelled with Biodiesel-Diesel Blends Containing 5\% Bioethanol. Entropy 2016, 18, 387. [CrossRef]

9. Blakemore, F.; Davies, C.; Isaac, J. Effects of changes in the UK energy-demand and environmental legislation on atmospheric pollution by oxides of nitrogen and black smoke. Appl. Energy 2001, 68, 83-117. [CrossRef]

10. Baukal, C.E., Jr. The John Zink Hamworthy Combustion Handbook, Fundamentals, 2nd ed.; CRC Press: Boca Raton, FL, USA, 2013; Volume 1, ISBN 978-1-4398-3962-1.

11. Farid, M.A.A.; Hassan, M.A.; Roslan, A.M.; Samsudin, M.H.; Mohamad, Z.J.J.; Othman, M.R.; Shirai, Y. Carbon monoxide reduction in the flue gas during biochar production from oil palm empty fruit bunch. J. Clean. Prod. 2020, 258, 120580. [CrossRef]

12. Kapitány, S.; Nagy, D.; Posta, J.; Béni, Á. Determination of atmospheric sulphur dioxide and sulphuric acid traces by indirect flame atomic absorption method. Microchem. J. 2020, 157, 104853. [CrossRef]

13. Heywood, J.B. Internal Combustion Engine Fundamentals; Hill Series in Mechanical Engineering; McGraw: New York, NY, USA, 1988; ISBN 0-07-028637-X.

14. Renzi, M.; Patuzzi, F.; Baratieri, M. Syngas feed of micro gas turbines with steam injection: Effects on performance, combustion and pollutants formation. Appl. Energy 2017, 206, 697-707. [CrossRef]

15. Elsner, W.; Wysocki, M.; Niegodajew, P.; Borecki, R. Experimental and economic study of small-scale CHP installation equipped with downdraft gasifier and internal combustion engine. Appl. Energy 2017, 202, 213-227. [CrossRef]

16. Singh, S.; Chakraborty, J.P.; Mondal, M.K. Pyrolysis of torrefied biomass: Optimization of process parameters using response surface methodology, characterization, and comparison of properties of pyrolysis oil from raw biomass. J. Clean. Prod. 2020, 272, 122517. [CrossRef]

17. Allesina, G.; Pedrazzi, S.; Allegretti, F.; Morselli, N.; Puglia, M.; Santunione, G.; Tartarini, P. Gasification of cotton crop residues for combined power and biochar production in Mozambique. Appl. Therm. Eng. 2018, 139, 387-394. [CrossRef] 
18. Li, L.; Yao, Z.; You, S.; Wang, C.-H.; Chong, C.; Wang, X. Optimal design of negative emission hybrid renewable energy systems with biochar production. Appl. Energy 2019, 243, 233-249. [CrossRef]

19. Belgiorno, G.; Dimitrakopoulos, N.; Di Blasio, G.; Beatrice, C.; Tunestål, P.; Tunér, M. Effect of the engine calibration parameters on gasoline partially premixed combustion performance and emissions compared to conventional diesel combustion in a light-duty Euro 6 engine. Appl. Energy 2018, 228, 2221-2234. [CrossRef]

20. Mueller, C.J.; Nilsen, C.W.; Ruth, D.J.; Gehmlich, R.K.; Pickett, L.M.; Skeen, S.A. Ducted fuel injection: A new approach for lowering soot emissions from direct-injection engines. Appl. Energy 2017, 204, 206-220. [CrossRef]

21. Mason, J.; Kaufmann, B.; Tartarini, P.; Puglia, M.; Morselli, N.; Veratti, G.; Bigi, A. Compression Ratios Comparisons between Engines Operating with Producer Gas. Eur. Biomass Conf. Exhib. Proc. 2019, 2019, 1927-1931. [CrossRef]

22. Puglia, M.; Morselli, N.; Ottani, F.; Tartarini, P. Implementation of a Portable Petrol—Powered Generator Fueled through a Tabletop Biomass Gasifier. In Proceedings of the 28th European Biomass Conference and Exhibition, e-EUBCE 2020, Marseille, France, 6-9 July 2020; ETA-Florence Renewable Energies: Florence, Italy, 2019; pp. 396-400.

23. Bhattacharyya, S.; Das, R.K. Catalytic reduction of NOx in gasoline engine exhaust over copper- and nickel-exchanged X-zeolite catalysts. Energy Convers. Manag. 2001, 42, 2019-2027. [CrossRef]

24. All Power Labs Inc. Available online: http:/ / www.allpowerlabs.com/ (accessed on 12 November 2020).

25. MRU Instruments, Inc. Available online: http://www.mru-instruments.com/wp-content/uploads/2015/04/VARIO-plusindustrial-Brochure-2015.pdf (accessed on 13 November 2020).

26. Zhejiang Anlu Cleaning Machinery Co., Ltd. Available online: https://www.anlu.com/product/n-series/ (accessed on 12 November 2020).

27. Focus Technology Co., Ltd. Available online: https://it.made-in-china.com/co_cn-generator/product_Gasoline-Engine-168F-1_hrhyiyhng.html (accessed on 14 November 2020).

28. Maneerung, T.; Li, X.; Li, C.; Dai, Y.; Wang, C.-H. Integrated downdraft gasification with power generation system and gasification bottom ash reutilization for clean waste-to-energy and resource recovery system. J. Clean. Prod. 2018, 188, 69-79. [CrossRef]

29. Pedrazzi, S.; Allesina, G.; Puglia, M.; Guidetti, L.; Tartarini, P. ICOPE-15-1004 Increased maize power production through an integrated biogas-gasification-SOFC power system. In Proceedings of the International Conference on Power Engineering (ICOPE), Yokohama, Japan, 15 April 2015; Japan Society of Mechanical Engineers: Sapporo, Japan, 2015; Volume 2015.12.

30. dos Santos, R.G.; Bordado, J.C.; Mateus, M.M. Estimation of HHV of lignocellulosic biomass towards hierarchical cluster analysis by Euclidean's distance method. Fuel 2018, 221, 72-77. [CrossRef]

31. Kul, B.S.; Ciniviz, M. Assessment of waste bread bioethanol-gasoline blends in respect to combustion analysis, engine performance and exhaust emissions of a SI engine. Fuel 2020, 277, 118237. [CrossRef]

32. IUPAC. Available online: https://iupac.org/wp-content/uploads/2018/12/IUPAC_Periodic_Table-01Dec18.pdf (accessed on 10 November 2020).

33. Bergman, T.L.; Lavine, A.S.; Incropera, F.P.; Dewitt, D.P. Fundamentals of Heat and Mass Transfer, 7th ed.; Wiley: Hoboken, NJ, USA, 2011; ISBN 978-0470-50197-9.

34. Naterer, G.F. Advanced Heat Transfer, 2nd ed.; CRC Press: Boca Raton, FL, USA, 2018; ISBN 9781138579323.

35. Rohsenow, W.M.; Hartnett, J.P.; Cho, Y.I. Handbook of Heat Transfer, 3rd ed.; McGraw-Hill: New York, NY, USA, 1998; ISBN 0-07-053555-8.

36. Ngamsidhiphongsa, N.; Ponpesh, P.; Shotipruk, A.; Arpornwichanop, A. Analysis of the Imbert downdraft gasifier using a species-transport CFD model including tar-cracking reactions. Energy Convers. Manag. 2020, 213, 112808. [CrossRef]

37. Din, Z.U.; Zainal, Z. Tar reduction mechanism via compression of producer gas. J. Clean. Prod. 2018, 184, 1-11. [CrossRef]

38. Kamble, P.; Khan, Z.; Gillespie, M.; Farooq, M.; McCalmont, J.; Donnison, I.; Watson, I. Biomass gasification of hybrid seed Miscanthus in Glasgow's downdraft gasifier testbed system. Energy Procedia 2019, 158, 1174-1181. [CrossRef]

39. Ayub, H.M.U.; Park, S.J.; Binns, M. Biomass to Syngas: Modified Stoichiometric Thermodynamic Models for Downdraft Biomass Gasification. Energies 2020, 13, 5383. [CrossRef]

40. Pedrazzi, S.; Allesina, G.; Morselli, N.; Puglia, M.; Rinaldini, C.A.; Savioli, T.; Mattarelli, E.; Leonardi, C.; Giorgini, L.; Tar-tarini, P. Modified Diesel engine fueled by syngas: Modeling and experimental validation. In Proceedings of the European Biomass Conference and Exhibition, Amsterdam, The Netherlands, 6-9 June 2016; ETA-Florence Renewable Energies: Florence, Italy, 2016; Volume 2016, pp. 880-883.

41. Vakalis, S.; Patuzzi, F.; Baratieri, M. Thermodynamic modeling of small scale biomass gasifiers: Development and assessment of the "Multi-Box" approach. Bioresour. Technol. 2016, 206, 173-179. [CrossRef]

42. Soares, J.; Oliveira, A.C. Experimental assessment of pine wood chips gasification at steady and part-load performance. Biomass Bioenergy 2020, 139, 105625. [CrossRef]

43. Yan, W.-C.; Shen, Y.; You, S.; Sim, S.H.; Luo, Z.-H.; Tong, Y.W.; Wang, C.-H. Model-based downdraft biomass gasifier operation and design for synthetic gas production. J. Clean. Prod. 2018, 178, 476-493. [CrossRef]

44. Sridhar, G.; Yarasu, R.B. Facts about Producer Gas Engine Paths to Sustainable Energy. Artie, N., Ed.; InTech: London, UK, 2010. Available online: http:/ / www.intechopen.com/books/paths-to-sustainable-energy/facts-about-producer-gas-engine (accessed on 18 November 2020).

45. Monsalve-Serrano, J.; Belgiorno, G.; Di Blasio, G.; Guzmán-Mendoza, M. 1D Simulation and Experimental Analysis on the Effects of the Injection Parameters in Methane-Diesel Dual-Fuel Combustion. Energies 2020, 13, 3734. [CrossRef] 